\title{
www.czasopisma.pan.pl \\ Aluminium Alloys Smelting in Shaft- Reverberatory Furnaces in a Liquid Bath Mode
}

\author{
V. Grachev \\ A.N. Frumkin Institute of Physical Chemistry and Electrochemistry of the Russian Academy of Sciences, 29 Bldg 1, \\ Bolshaya Ordynka St., Suite \# 104, 119017 Moscow, Russia \\ Corresponding author. E-mail address: chernitsa@vernadsky.ru
}

Received 17.02.2017; accepted in revised form 05.05.2017

\begin{abstract}
The aim of research was creation of a furnace for aluminum alloys smelting "in a liquid bath" in order to reduce metal loss. In the paper, the author demonstrates the results of research on smelting of aluminum alloys in a shaft-reverberatory furnace designed by the author. It has been shown that smelting aluminum alloy in a liquid bath was able to significantly reduce aluminum loss and that shaft-reverberatory design provided high efficiency and productivity along with lower energy costs. Ensuring continuous operation of the liquid bath and superheating chamber, which tapped alloy with the required texture, was achieved by means of the optimal design of partition between them. The optimum section of the connecting channels between the liquid bath of smelting and the superheating chamber has been theoretically substantiated and experimentally confirmed. The author proposed a workable shaft-reverberatory furnace for aluminum alloys smelting, providing solid charge melting in a liquid bath.
\end{abstract}

Keywords: Innovative foundry technologies and materials, Heat treatment, Aluminum alloys smelting, Shaft-reverberatory furnace, Heat balance

\section{Introduction}

For the purpose of aluminum alloy smelting, different types of furnaces are used in the foundry industry, depending on the scale of production, on the type and purpose of casting. The most widely used types of furnaces are electric resistance crucible furnaces and electric induction furnaces (gas-fired crucible furnaces and reverberatory furnaces) $[1,2]$. In recent years, the so-called shaft furnaces have appeared, the technological and thermotechnical capabilities of which have as yet been insufficiently studied [3]. The very principle of the shaft-bath furnace's operation involves one of the major advantages of such furnace type - continuous operation [1]. This advantage is particularly evident in mass production, when the manufacturing of aluminum alloys may be automated.

The advantages of gas-fired shaft-bath furnaces, especially for mass production, are not confined to the mere capability of continuous operation. Such a furnace is characterized by the following features: waste-heat recovery allows for a significant reduction in specific fuel consumption; smelting of the preheated charge under the heel of melted metal makes it possible to minimize the irrecoverable losses of metal; the maintenance costs of such furnaces is lowered, since the continuous process is easier to automate and mechanize, and the manning level may be reduced as well; the furnace elements most subjected to wear (e.g. lining) are enjoying improved conditions [3]. 
The combination of physical and chemical properties of aluminum casting alloys, including high thermal conductivity, low melting temperature, and high chemical activity coupled with rather high protective properties of the oxide film, define the specifics of the smelting process and imply the possibility of using almost all known melting methods.

The disadvantages of the reverberatory furnaces are the increased fuel consumption, local overheating of the melt, nonuniformity of distribution of alloying components, and low efficiency $14-30 \%$ [4].

\section{Methods and design}

The shaft furnace enables smelting in a continuous mode, which makes it possible to completely mechanize and automate the production process. The author was the first to propose a fully functional furnace (Figure 1) [3].

Loss of aluminum is the key concern as to the operating economy of such furnace. There many works on the kinetics of aluminum oxidation $[4,5]$.

Most of the authors, when studying the kinetics of aluminum alloys oxidation, determined the quantity of oxidized alloy based on the weight changes of the samples before and after the experiments. The oxide film forming on the surface of aluminum belongs to the thin coatings. At a room temperature, the thickness of the oxide film is $10-30 \AA$. As the temperature increases, the thickness of the oxide film increases too: at $573 \mathrm{~K}$, it is $200 \AA$, and under temperatures $773-873 \mathrm{~K}$, it amounts to $20000 \AA$. When exposed for an hour at $973 \mathrm{~K}$, an oxide film layer having thickness of $9000 \AA$ is formed on the surface, and at $1073 \mathrm{~K}$, the film thickness reaches $20000 \AA$.

Aluminum oxidation has become of particular interest worldwide [7-19]. When smelting aluminum alloys, the thickness of the oxide film forming on the surface largely depends of the method of melting solid pieces of the charge in the furnace: in a drop-stream mode or under a layer of liquid metal (in a liquid bath).

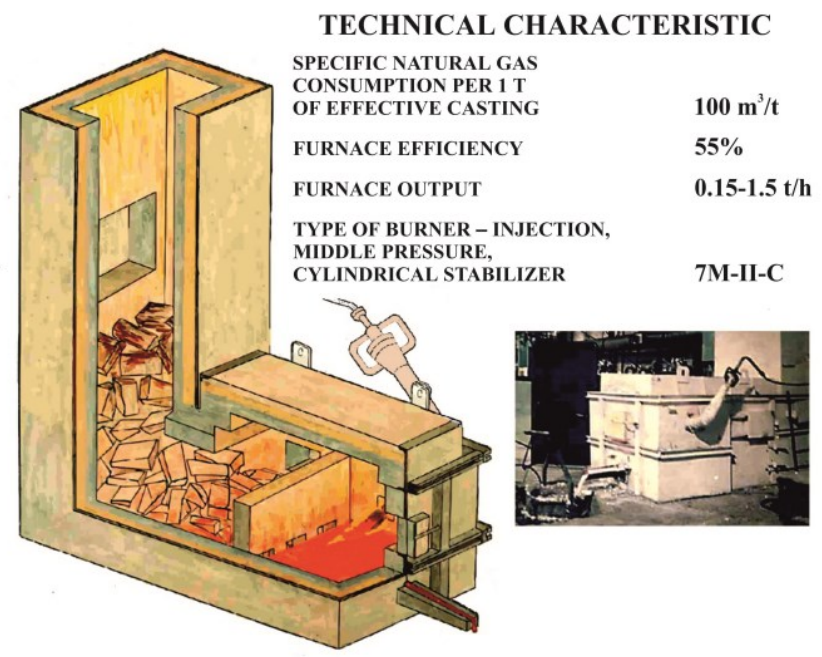

Fig. 1. Shaft-reverberatory furnace for aluminum alloys smelting

\section{Results}

In the present work, the quantitative comparison of the mentioned processes was performed based on calculations of the mass fraction of the oxide film forming during heating and melting on the surface of aluminum.

Thickness of oxide film was calculated on the surface of one piece of the charge. A standard ingot of AK5M2 GOST 1583-89 alloy, having a mass $\mathrm{M}$ of $15 \mathrm{~kg}$ and a surface area $\mathrm{F}=0.35 \mathrm{~m}^{2}$, was taken as a piece of charge.

In the shaft of the furnace, the charge is heated to $873 \mathrm{~K}$. According to [6], at a temperature of $773-873 \mathrm{~K}$, the thickness of the oxide film is $2 \cdot 10^{-7} \mathrm{~m}$. The mass $(\mathrm{kg})$ of oxide film of one ingot will be:

$M_{i f}=\Omega_{i} \cdot \delta_{f} \cdot \rho_{f}=0.35 \cdot 2 \cdot 10^{-7} \cdot 2700=0.19 \cdot 10^{-3}$

where $\rho_{f}=2700 \mathrm{~kg} / \mathrm{m}^{3}$ is the density of $\mathrm{Al}_{2} \mathrm{O}_{3}$.

The volume of the charge of the furnace in working in longitudinal magnetic field is $V_{c h}=0.95 \mathrm{~m}^{3}$; the bulk density of the charge is $\rho_{b}=1000 \mathrm{~kg} / \mathrm{m}^{3}$; number of ingots in the shaft is $N_{i}$ $=63$ pcs.

The mass $(\mathrm{kg})$ of oxide film of all ingots in the shaft is:

$M_{f}^{s h}=M_{i f} \cdot N_{i}=0.19 \cdot 10^{-3} \cdot 63=11.97 \cdot 10^{-3}$

The total area of heel of metal in the smelting and superheating chamber is $2.55 \mathrm{~m}^{2}$.

The mass $(\mathrm{kg})$ of oxide film in the bath is:

$M_{f}^{b}=F^{b} \cdot \delta_{f}^{b} \cdot \rho_{f}=2.55 \cdot 2 \cdot 10^{-6} \cdot 2700=13.77 \cdot 10^{-3}$

where $\delta_{f}^{b}=2 \cdot 10^{-6} \mathrm{~m}$ - thickness of oxide film at $1073 \mathrm{~K}$.

The total mass $(\mathrm{kg})$ of oxide film, when smelting under a layer of melt, amounts to:

$M_{f}=M_{f}^{s h}+M_{f}^{b}=(11.97+13.77) \cdot 10^{-3}=25.74 \cdot 10^{-3}$

When calculating the total mass of the oxide film, for the drop-stream melting mode, it was assumed that $50 \%$ is in the stream form and leaking into the bath. It is known that the mass of one ingot is $15 \mathrm{~kg}$. Given that $50 \%$ of this mass is smelted into drops, the total mass of molten drops will be $7.5 \mathrm{~kg}$.

The diameter $(\mathrm{m})$ of the lose drop is determined according to formula:

$d_{d}=4.815+0.121^{0.11 \mathrm{hg}}=0.0052$

where $h g=2 \mathrm{~kg} / \mathrm{m}^{2}-$ dynamic head of gases.

The surface $\left(\mathrm{m}^{2}\right)$ of the lose drop, when it is in the countercurrent, is close to the surface of the ball: 


$$
\Omega_{d}=\pi d_{d}^{2}=8.6 \cdot 10^{-5}
$$

The mass $(\mathrm{kg})$ of one drop is:

$$
M_{d}=V_{d} \rho=\frac{\pi d^{3}}{6} \rho=2.02 \cdot 10^{-4}
$$

Total number of drops is:

$$
n=\frac{0.5 M_{i}}{M_{d}}=74257
$$

Total surface area $\left(\mathrm{m}^{2}\right)$ of the falling drops is:

$$
\Omega_{\text {dtotal }}=\Omega_{d} \cdot n=6.4
$$

Total mass $(\mathrm{kg})$ of oxide film on the surface of the falling drops will be:

$$
M_{d f}=\Omega_{d t o t a l} \cdot \delta_{f} \cdot \rho_{f}=3.5 \cdot 10^{-3}
$$

When calculating the total mass of oxide film for stream-like leaking of the melt into the bath, it was assumed that the diameter of the stream was equal to $5 \mathrm{~mm}$, thus the length $(\mathrm{m})$ of the leaking stream of one half of weight of the ingot will be:

$$
d_{s}=\frac{V_{s}}{\pi R^{2}}=\frac{0.5 M_{i}}{\rho \pi R^{2}}=\frac{7.5}{2700 \cdot 3.14 \cdot 6.25 \cdot 10^{-6}}=141.5
$$

where $V_{s}$ - volume of the stream (cylinder), $\mathrm{m}^{3} ; R$ - radius of the stream, $\mathrm{m}$

The surface area $\left(\mathrm{m}^{2}\right)$ of the stream is:

$$
\Omega_{s}=\alpha_{s} \cdot 2 \pi R=141.5 \cdot 1.57 \cdot 10^{-2}=2.22
$$

The volume $\left(\mathrm{m}^{3}\right)$ of the oxide film on the surface of the stream is:

$$
V_{s f}=\Omega_{s} \cdot \delta_{f}=2.22 \cdot 2 \cdot 10^{-7}=4.44 \cdot 10^{-7}
$$

The mass $(\mathrm{kg})$ of the oxide film on the surface of the stream:

$$
M_{s f}=V_{s f} \cdot \rho_{f}=4.44 \cdot 10^{-7} \cdot 2700=1.2 \cdot 10^{-3}
$$

Total mass $(\mathrm{kg})$ of the oxide film on the surface of one ingot, when smelting in the drop-stream mode, will be:

$$
\begin{aligned}
& M_{f}^{\prime \prime}=N_{i} \cdot M_{d s}+M_{f}^{s h}+M_{f}^{b}=63 \cdot 4.7 \cdot 10^{-3}+11.97 \cdot 10^{-3} \\
& +13.77 \cdot 10^{-3}=321.84 \cdot 10^{-3}
\end{aligned}
$$

Thus, when smelting the pieces of the charge under a layer of melt, i.e. in the liquid bath, the mass fraction of the oxide film relative to the mass of metal (\%), based on the furnace output per hour, will be:

$M^{\prime}=\frac{25.74 \cdot 10^{-3}}{810} \cdot 100 \%=3.18 \cdot 10^{-3}$

When smelting the charge in the drop-stream mode, the mass fraction of the oxide film relative to the mass of metal (\%), based on the furnace output per hour, will be:

$M^{\prime \prime}=\frac{321.84 \cdot 10^{-3}}{810} \cdot 100 \%=3.97 \cdot 10^{-2}$

Thus, in the drop-stream melting mode, the loss of aluminum is 12.5 times higher than in the under-layer melting mode. Our design of the furnace enables exactly the under-layer smelting in the liquid bath.

Since liquid and solid metals are contacting each other in the smelting chamber, the bath temperature here is close to the melting temperature, and in the superheating chamber it must be higher in order to ensure the smelting and treatment of the melt.

Initial data for calculating the optimal size of the chambers:

$G=1000.0$ - furnace output per hour, $\mathrm{kg} /$ hour;

$\rho=2700.0-$ density of aluminum, $\mathrm{kg} / \mathrm{m}^{3}$;

$H=0.5-$ depth of bath with the melt, m;

$\xi=0.9-$ coefficient;

$L_{a}=0.265$ - consumption of air per $1000 \mathrm{~kJ}$ of gas combustion, $\mathrm{m}^{3}$;

$L_{f g}=0.296-$ volume of flue gases per $1000 \mathrm{~kJ}$ of gas combustion, $\mathrm{m}^{3}$;

$t_{a i}=20.0-$ temperature of the blown-in air, and the air surrounding the furnace, ${ }^{\circ} \mathrm{C}$;

$T_{0}=293.0$ - temperature of the blown-in air, and the air surrounding the furnace, $\mathrm{K}$;

$t_{n g}=20.0-$ temperature of the natural gas, ${ }^{\circ} \mathrm{C}$;

$\xi_{p y r}=0.8$ - pyrometric coefficient of fuel burning in the furnace;

$\xi_{\text {pyrf }}=0.7$ - pyrometric coefficient of the furnace;

$\varepsilon_{n}=0.2$ - oxidized aluminum emissivity factor;

$C_{0}=5.67$ - radiation coefficient of an absolute black body, $\mathrm{W} / \mathrm{m}^{2} \cdot \mathrm{K}^{4}$

$T_{m i}=933.0$ - initial temperature of metal;

$T_{m f}=1023.0-$ final temperature of metal;

$\alpha_{\text {conv }}=15.0-$ convection coefficient, $\mathrm{W} / \mathrm{m}^{2} \cdot \mathrm{K}$;

$g p I=385180.0-$ latent heat of melting of aluminum, $\mathrm{W} \cdot \mathrm{sec} / \mathrm{kg} \cdot \mathrm{K}$

$g p I=385.18$ - latent heat of melting of aluminum, $\mathrm{kJ} / \mathrm{kg}$;

$C_{m} I=1.081-$ mean heat capacity of liquid aluminum, $\mathrm{kJ} / \mathrm{kg} \cdot{ }^{\circ} \mathrm{C}$;

$C_{m}=1081.0-$ mean heat capacity of liquid aluminum, $\mathrm{W} \cdot \mathrm{sec} / \mathrm{kg} \cdot \mathrm{K}$

$C_{m}^{2}=897.0$ - heat capacity of aluminum at $\mathrm{T}=293 \mathrm{~K}$, $\mathrm{W} \cdot \mathrm{sec} / \mathrm{kg} \cdot \mathrm{K}$

$i_{g} I=430000.0$ - enthalpy of combustion products at $573 \mathrm{~K}$, $\mathrm{W} \cdot \mathrm{sec} / \mathrm{m}^{3}$;

$X I=0.23-$ thickness of refractory brickwork, m; 
$X 2=0.065-$ thickness of insulation layer (foam-chamotte

brickwork), m;

$F_{d}=0.21-$ area of doors, $\mathrm{m}^{2}$;

$W=0.25$ - orifice coefficient;

$P S I=0.5-$ time during which the door is open;

$\mu=0.52-$ consumption coefficient;

$H I=0.3$ - height of the door, $\mathrm{m}$;

$B I=0.1-$ width of slit of the door, $\mathrm{m}$;

$g I=9.8-$ free-fall acceleration, $\mathrm{m} / \mathrm{sec}$;

$\rho_{a}=1.293$ - density of air, $\mathrm{kg} / \mathrm{m}^{3}$;

$\rho_{g}=1.17-$ density of gas, $\mathrm{kg} / \mathrm{m}^{3}$;

$\lambda=230.0-$ coefficient of heat conductivity of the alloy at $\mathrm{T}=600$

$\mathrm{K}, \mathrm{W} / \mathrm{m} \cdot \mathrm{K}$

$\alpha_{v}=2000.0-$ coefficient; $d=0.2$ - diameter of a charge piece, $\mathrm{m}$;

$f I=0.5-$ void volume of the charge layer;

$\rho_{b}=1000.0$ - bulk weight of the charge (aluminum ingot), $\mathrm{kg} / \mathrm{m}^{3}$;

cro $=1000.0$ - heat capacity of aluminum charge, $\mathrm{W} \cdot \mathrm{sec} / \mathrm{kg} \cdot \mathrm{K}$;

$\omega_{0}=0.5-$ speed of outflow of combustion products in an empty shaft, $\mathrm{m} / \mathrm{sec}$;

$\xi_{p}=0.4$ - adopted furnace efficiency;

$t_{b s}=600.0-$ temperature of the brickwork surface adjacent to the insulation layer, ${ }^{\circ} \mathrm{C}$.

The purpose of the thermotechnical calculation is to ensure the required temperature difference in the smelting chamber and the superheating chamber and that the connecting channels do not cool the metal in the superheating chamber.

Table 1.

Structural sizes of a bath-shaft furnace for aluminum smelting, productivity of $1.5 \mathrm{t} / \mathrm{h}$

Parameter

Effective length of the beam, $\mathrm{S}_{\mathrm{ef}}$

Lower heating value of fuel, $Q_{n r}$

Air volume, $\mathrm{V}_{\mathrm{a}}$

Combustion products volume, $\mathrm{V}_{\mathrm{cp}}$

Calorimetric flame temperature, $\mathrm{T}_{\mathrm{c}}$

Actual combustion temperature, $\mathrm{T}_{\mathrm{a}}$

Average temperature inside the furnace, $T_{\text {if }}$

Temperature of the brickwork of the bath, $t_{b b}$

Reduced coefficient of radiation, $\mathrm{C}_{\mathrm{r}}$

Radiation heat transfer coefficient, $\alpha_{i}$

Aggregate coefficient of heat transfer, $\alpha_{E}$

Heat flow, $\mathrm{gm}_{\mathrm{m}}$

Area of contact of the melt with combustion products, FII

Adjusted value of the bath's characteristic dimension, A3

Bath length, A4

Bath width, A5

Effective length of the beam, $\mathrm{S}_{\mathrm{ef}} \mathrm{I}$

Brickwork development degree, $\omega$

Temperature of the bath's brickwork, $\mathrm{t}_{\mathrm{bb}} \mathrm{I}$

Heat required for heating the charge to the melting temperature in the furnace shaft, $\mathrm{Q}_{\text {chmt }}$

Heat carried away by flue gases, Qgas

Area of the bath's brickwork, Fb

Heat loss through the bath's brickwork, $\mathrm{Q}_{\mathrm{bb}}$

Heat loss due to radiation through open doors in the bath, Q Qrob

Heat loss due gases leaking through the doors in the bath, Qgob

Aggregate volumetric heat transfer coefficient, $K_{v}$

Average ratio of water equivalents of shaft, $\mathrm{Z}_{\mathrm{avg}}$

Cross-section area of the shaft, $F_{\text {sh }}$

Volumetric heat capacity of the charge, VI

Height of the shaft, $\mathrm{H}_{\text {sh }}$

Area of the brickwork of the furnace shaft, $F_{\text {shb }}$

Width of the furnace shaft, $\mathrm{B}_{\mathrm{f}}$

Length of the furnace shaft, $l_{\mathrm{f}}$

Heat loss through the shaft brickwork, $\mathrm{Q}_{\text {shb }}$

Adjusted value of gas consumption, B2

Heat carried away by flue gases, $\mathrm{Q}_{\text {gas }} \mathrm{I}$

Adjusted value of heat input, $\mathrm{Qhi}_{\mathrm{hi}}$

Furnace efficiency, eta

\begin{tabular}{|c|c|}
\hline Unit & Value \\
\hline$\mu \mathrm{m}$ & 0.75895 \\
\hline $\mathrm{kJ} / \mathrm{m}^{3}$ & 34720640.00 \\
\hline $\mathrm{m}^{3}$ & 9.20 \\
\hline $\mathrm{m}^{3}$ & 10.28 \\
\hline $\mathrm{K}$ & 2323.00 \\
\hline K & 1858.40 \\
\hline $\mathrm{K}$ & 1300.88 \\
\hline${ }^{\circ} \mathrm{C}$ & 975.74 \\
\hline $\mathrm{W} / \mathrm{m}^{2} \cdot \mathrm{K}^{4}$ & 2.150 \\
\hline $\mathrm{W} / \mathrm{m}^{2} \cdot \operatorname{deg}$ & 155.428 \\
\hline $\mathrm{W} / \mathrm{m}^{2} \cdot \operatorname{deg}$ & 170.428 \\
\hline $\mathrm{W} / \mathrm{m}^{2}$ & 55027.92 \\
\hline $\mathrm{m}^{2}$ & 3.9455 \\
\hline $\mathrm{m}^{2}$ & 1.4045 \\
\hline $\mathrm{m}^{2}$ & 2.8091 \\
\hline $\mathrm{m}^{2}$ & 1.4045 \\
\hline$\mu \mathrm{m}$ & 1.01127 \\
\hline $\mathrm{m}^{2}$ & 4.0000 \\
\hline${ }^{\circ} \mathrm{C}$ & 996.45 \\
\hline $\mathrm{W}$ & 288266.67 \\
\hline $\mathrm{W}$ & 155693.93 \\
\hline $\mathrm{m}^{2}$ & 8.104 \\
\hline $\mathrm{W}$ & 11462.00 \\
\hline $\mathrm{W}$ & 1616.28 \\
\hline $\mathrm{W}$ & 12768.07 \\
\hline \multirow[t]{2}{*}{$\mathrm{W} / \mathrm{m}^{3} \cdot \mathrm{deg}$} & 1980.86 \\
\hline & 0.7564 \\
\hline $\mathrm{m}^{2}$ & 0.7242 \\
\hline $\mathrm{kJ} / \mathrm{m}^{3} \cdot \mathrm{deg}$ & 1000000.00 \\
\hline $\mathrm{m}$ & 3.5776 \\
\hline $\mathrm{m}^{2}$ & 13.7389 \\
\hline $\mathrm{m}$ & 1.40454 \\
\hline $\mathrm{m}$ & 0.51558 \\
\hline $\mathrm{W}$ & 11764.56 \\
\hline $\mathrm{m}^{3} / \mathrm{sec}\left(\mathrm{Nm}^{3} /\right.$ hour $)$ & 0.0197 \\
\hline $\mathrm{W}$ & 86881.41 \\
\hline $\mathrm{W}$ & 682600.68 \\
\hline & 0.7168 \\
\hline
\end{tabular}


In order to define dimensions of the transition channel, analytical calculations and experimental studies were conducted. During analytical calculations, a physical model of heat processes occurring in the gas-fired bath-shaft furnace was developed. It consists in the following.

In the superheating chamber, there is a heat flow from the overheated top layers of the melt to the bottom layers. The bottom layers of the melt have a lower temperature due to continuous inflow of "cold" melt from the smelting chamber. In the superheating chamber, the heat is transferred from the heel of metal to the bottom layers of the bath:

$Q_{I}=g_{I} \cdot F$

where $\mathrm{F}$ is the heel of metal area in the superheating chamber.

Between the melt located in the smelting chamber and the superheating chamber, there is an ever-present temperature gradient. In the superheating chamber, the melt is always to be superheated to a temperature of $760{ }^{\circ} \mathrm{C}$, and in the smelting chamber, the metal is always "cold" due to continuous smelting of the charge under the layer of the melt, with temperature approximately equal to the melting temperature of the alloy. The melting temperature of $\mathrm{Al}$ is $660^{\circ} \mathrm{C}$. In aluminum-silicon alloys, the solidus temperature is $548{ }^{\circ} \mathrm{C}$. The liquidus temperature decreases from $660{ }^{\circ} \mathrm{C}$ to $577{ }^{\circ} \mathrm{C}$ at $\mathrm{Si}$ content of $12.6 \%$. Magnesium significantly reduces these temperatures.

Due to constant temperature gradient between the melt in the superheating chamber and the melt in the melting chamber, in the melt there is a heat flow $q_{2}=\lambda / l\left(T_{M}^{\prime}-T_{M}^{\prime \prime}\right)$ through the connecting channels, opposite to the direction of the melt movement in the furnace. Thus, from the superheating chamber to the melting chamber, through the connecting channels, the heat is transferred:

$Q_{2}=\frac{\lambda}{l}\left(T_{M}^{\prime}-T_{M}^{\prime \prime}\right) \cdot f$

where $\lambda$ - coefficient of heat conductivity of liquid aluminum, $\mathrm{W} / \mathrm{m} \cdot \mathrm{K} ; l-$ thickness of the partition of the connecting channel, $\mathrm{m} ; f$ - cross-section area of the connecting channel, $\mathrm{m}^{2} ; T_{M}^{\prime}$ and $T_{M}^{\prime \prime}$ - temperature of metal in the superheating chamber and in the smelting chamber respectively, $\mathrm{K}$.

The "cold" melt located in the melting chamber constantly takes the heat from the melt in the superheating chamber through the connecting channels located in the bottom part of refractory partition. Since the heat flow $q_{2}$ from the melt in the superheating chamber to the melt in the melting chamber is bigger than the flow $q_{1}$ from the upper layers of the melt to the bottom layers in the superheating chamber because of the difference in temperature gradient, the increased cross-section area of connecting channels can cause chilling of the melt in the superheating chamber.
Three chromel-alumel thermocouples TChA-0806 were installed in the shaft and in the reverberatory part of the furnace in order to study the temperature mode and the correctness of choice of the overall furnace design ensuring continuous operation of the furnace, i.e. the even heating of the charge in the shaft, the smelting of the charge in the smelting chamber under the melt layer (in the liquid bath), and the superheating of the melt in the superheating chamber to $760-780{ }^{\circ} \mathrm{C}$. In the shaft, the thermocouple was installed $150 \mathrm{~mm}$ higher than the charging door. The two remaining thermocouples were installed in the bath part of the furnace. One of them was installed at the transition section from the reverberatory part to the shaft, and the other was immersed in the overheated melt (Figure 2).

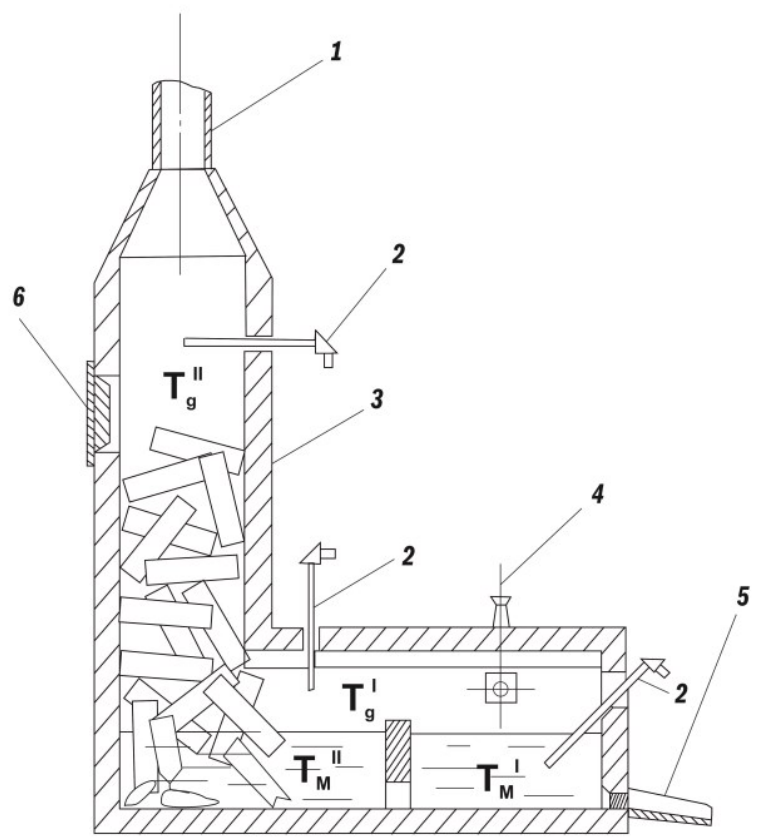

Fig. 2. Layout of studying the temperature mode of the shaftreverberatory furnace: 1 - flue gases outlet pipe, $2-$

thermocouples, 3 - shaft, 4 - burner, 5 - tapping spout, 6 charging door

In order to empirically determine the aggregate cross-section area $f$ of connecting channels, the refractory partition in the smelting bath of the shaft-reverberatory furnace was changed, so that it divided the bath into two chambers: the smelting chamber and the superheating chamber.

The results of the study on determination of the optimal crosssection of the aggregate area $f$ of the connecting channel between the smelting chamber and the superheating chamber are given in Table 2. 
Table 2.

Optimal cross-section of the aggregate area f of the connecting channel

\begin{tabular}{lllcc}
\hline \multirow{2}{*}{ No } & $f, \mathrm{~m}^{2}$ & $f / \mathrm{F}$ & \multicolumn{2}{c}{ Furnace operation data } \\
\cline { 3 - 4 } 1. & 0.024 & 0.03 & Temperature in the superheating chamber, ${ }^{\circ} \mathrm{C}$ & Efficiency $(\eta), \%$ \\
\hline 2. & 0.032 & 0.04 & $780-785$ & 53.1 \\
\hline 3. & 0.040 & 0.05 & $770-780$ & 55.2 \\
\hline 4. & 0.056 & 0.07 & $765-775$ & 58.5 \\
\hline 5. & 0.080 & 0.10 & $760-765$ & 59.6 \\
\hline 6. & 0.088 & 0.11 & $750-760$ & 60.1 \\
\hline 7. & 0.096 & 0.12 & $735-740$ & 56.3 \\
\hline 8. & 0.112 & 0.14 & $700-710$ & 54.3 \\
\hline 9. & 0.128 & 0.16 & $690-700$ & 51.2 \\
\hline 10. & 0.160 & 0.20 & $675-685$ & 49.4 \\
\hline
\end{tabular}

The conducted experiments have shown that the optimal cross-section area $f$ of connecting channels range between $(0.05$ $0.1) \cdot F$, which ensures a stable temperature of the melt in the superheating chamber and smelting in the liquid bath, i.e. minimum loss of metal.

When reducing the aggregate cross-section area $f$ of connecting channels to less than $0.05 \cdot \mathrm{F}$, i.e. at $0.04 \mathrm{~m}^{2}$, the inflow of liquid melt from the smelting chamber into the superheating chamber slows down. Due to this, the temperature in the superheating chamber increases, resulting in an increase in the loss of metal and reduction of efficiency and productivity of the furnace, while the fuel consumption rate remains constant.

When increasing the aggregate cross-section area $f$ of connecting channels to more than $0.1 \cdot \mathrm{F}$, i.e. to more than $0.08 \mathrm{~m}^{2}$, the melt temperature in the superheating chamber decreases due to intense inflow of the "cold" melt from the smelting chamber. Thus, making the aggregate cross-section area $f$ of connecting channels equal to $0.16 \mathrm{~m}^{2}$ results in an $80-90{ }^{\circ} \mathrm{C}$ decrease in the melt temperature, i.e. the melt temperature in the superheating chamber is reduced to $670-680{ }^{\circ} \mathrm{C}$.

At such an area of connecting channels cross-section, in order to superheat the melt in the superheating chamber to $760-780{ }^{\circ} \mathrm{C}$, it is necessary to temporarily stop feeding the charge so that avoid chilling of the melt in the smelting chamber, because this melt in turn takes the heat from the melt in the superheating chamber through connecting channels. In this case, the advantages of continuous operation are lost, and the increase of fuel consumption only leads to an unwanted overheating of the upper layers of the melt in the superheating chamber, increased metal loss, and reduced efficiency.

In order to ensure continuity of the smelting process, it is necessary to have a certain volume of the shaft, wherein the charge is heated from $T_{M}$ to $T_{S h}$ and immersed into the liquid bath in the smelting chamber, and melted under the layer of the liquid metal. In each case, the volume of the shaft is calculated through volumetric heat-transfer coefficient in the shaft $K_{V}$. The crosssection of the shaft is determined by design and aerodynamic factors and is verified by calculating the heat transfer in boundary conditions. Having the required volume and the cross-section of the shaft, the required height of the charge may be found easily.
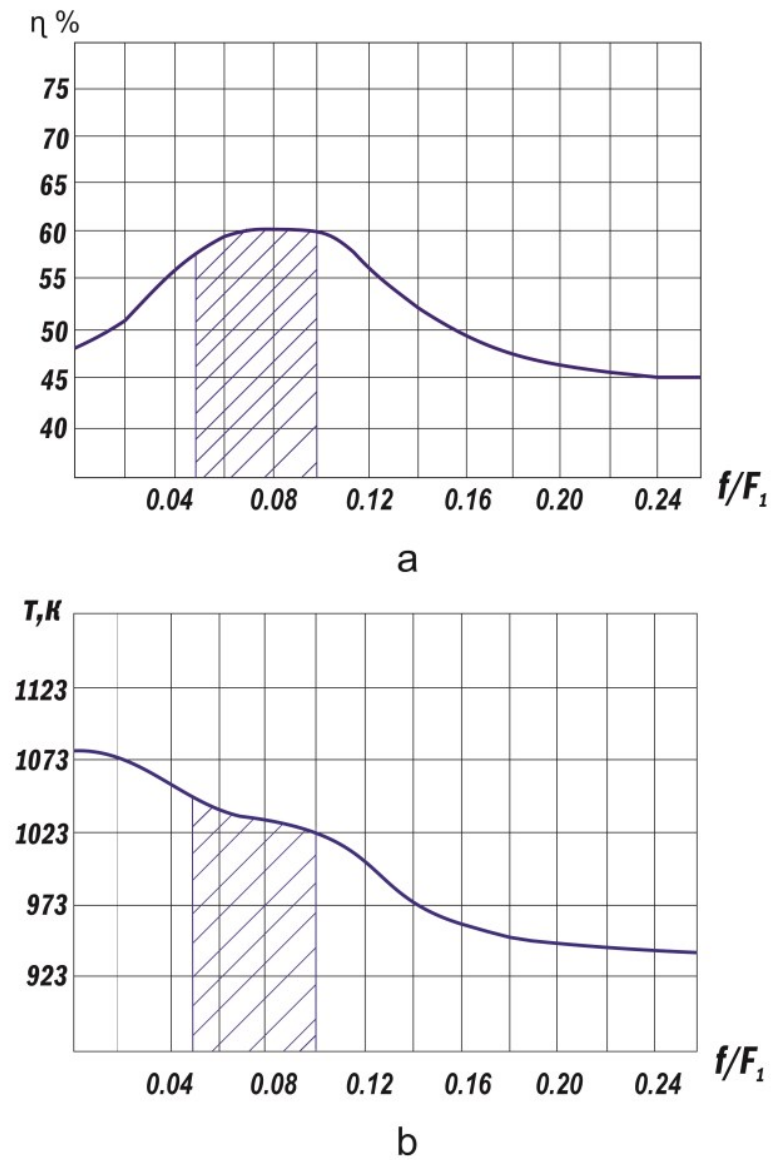

Fig. 3. Dependence of thermal efficiency of the furnace (a) and the temperature of metal in the superheating chamber (b) on the aggregate cross-section area of connecting channels 


\section{Conclusions}

The author proposed a workable shaft-reverberatory furnace for aluminum alloys smelting, providing solid charge melting in a liquid bath.

Studies of aluminum alloy smelting in such furnace led to the following conclusions:

1. Thickness of the oxide film formed on the surface of the pieces of the charge essentially depends on the charge melting method. When melting in the drop-stream mode, it is $3.97 \cdot 10^{-}$ $2 \%$ of the mass of the metal, whereas when melting under the liquid metal layer, it is $3.11 \cdot 10^{-3} \%$, thereby reducing metal loss by a factor of 12.8 .

2. In order to ensure continuous operation of the furnace, the author offered a furnace design with connecting channels between the smelting chamber and superheating chamber. It was established experimentally that the optimal cross-section area of connecting channels constituted $0.05-0.1$ of the heel of metal's surface area in the superheating chamber.

3. The efficiency of the furnace at the optimal section of connecting channels $f=(0.05-0.1) \cdot \mathrm{F}$ is equal to $58.5-60 \%$, which ensures high energy efficiency and low aluminum loss along with high economic efficiency of aluminum alloys smelting.

\section{References}

[1] Morgunov, V.N. (2009). Foundry Furnaces: Characteristics, analysis, and classification. Penza: Penza State University Publishing.

[2] Markmet Metallurgy. (2005). Technological characteristics of non-ferrous metals and alloys smelting in electric furnaces. Retrieved December 15, 2016, from http://markmet.ru/tehnologiya_metallov/tekhnologicheskieosobennosti-plavki-tsvetnykh-metallov-i-splavov-velektropech.

[3] Grachev, V.A., Golubyatnikov, M.I., Morgunov, V.N., Terekhov, V.S., Ignatiev, A.A. (1982). USSR certificate of authorship No. 972202. Shaft furnace for smelting aluminum alloys. Moscow: State Committee for Inventions and Discoveries.

[4] Postnikov, I.S., Cherkasov, V.V. (1973). Advanced methods of aluminum alloys smelting and casting. Moscow: Metallurgiya.

[5] Andreev, A.D., Gogin, V.B., Makarov, G.S. (1980). Highproductive smelting of aluminum alloys. Moscow: Metallurgiya.

[6] Lepinskikh, B.M., Kitaev, A.A., Belousov, A.A. (1979). Oxidation of liquid metals and alloys. Moscow: Nauka.
[7] Dudoladov, A.O., Buryakovskaya, O.A., Vlaskin, M.S., Zhuk, A.Z. \& Shkolnikov, E.I. (2015). Experimental study on low-temperature aluminium oxidation process accompanied by generation of hydrogen. International Scientific Journal for Alternative Energy and Ecology. 21, 112-120. DOI: 10.15518/isjaee.2015.21.013.

[8] Kleymenov, B.V., Mazalov, Yu.A., Bersh, A.V. \& Nizovtsev, V.E. (2005). Prospects for the hydrogen energy development based on aluminum. INFORMOST radioelectronics and telecommunication. 2(38), 62-64.

[9] Alinejad, B. \& Mahmoodi, K. (2009). A novel method for generating hydrogen by hydrolysis of highly activated aluminum nanoparticles in pure water. International Journal of Hydrogen Energy. 34, 7934-7938.

[10] Mahmoodi, K. \& Alinejad, B. (2010). Enhancement of hydrogen generation rate in reaction of aluminum with water. International Journal of Hydrogen Energy. 35, 52275232.

[11] Huang, X., Gao, T., Pan, X., Wei, D., Lv, C., Qin, L. \& Huang, Y. (2013). A Review: Feasibility of hydrogen generation from the reaction between aluminum and water for fuel cell applications. Journal of Power Sources. 229, 133-140.

[12] Parmuzina, A.V. \& Kravchenko, O.V. (2008). Activation of aluminium metal to evolve hydrogen from water. International Journal of Hydrogen Energy. 33, 3073-3076.

[13] Ilyukhina, A.V., Ilyukhin, A.S. \& Shkolnikov, E.I. (2012). Hydrogen generation from water by means of activated aluminium. International Journal of Hydrogen Energy. 37, 16382-16387.

[14] Rosenband, V. \& Gany, A. (2010). Application of activated aluminum powder for generation of hydrogen from water. International Journal of Hydrogen Energy. 35, 1089810904.

[15] Sinyavsky, V.S., Ustiyantsev, V.U. (1976). Corrosion protection of aluminum-alloy drill pipes. Moscow: Nedra.

[16] Putilova, I.N., Balezin, S.A., Barannik, V.P. (1958). Metal corrosion inhibitors. Moscow: Goskhimizdat.

[17] Shchukin, E.D. (1970). The Rehbinder Effect. In R. Bazurin, V. Bardin, K. Guseva, G. Kremneva (Eds.) International Yearbook "Science and Humanity" (pp. 337367). Moscow: Znanie.

[18] Korotkikh, A.G., Ionova, I.A., Karpovich, M.K. (2012). Research on the kinetics of oxidation and combustion of aluminum powders. In $18^{\text {th }}$ International Research and Practice Conference for Students, Postgraduates, and Young Scientists, 9-13 April 2012 (pp. 359-360). Tomsk, Russia: Tomsk Polytechnic University.

[19] Ohkura, Y., Rao, P.M. \& Zheng, X. (2011). Flash ignition of Al nanoparticles: Mechanism and applications. Combustion and Flame. 158, 2544-2548. 